\title{
Printed Hebrew Bibles in the Russian Academy of Science Library
}

\author{
D. D. Galtsin
}

For citation: Galtsin D. D. Printed Hebrew Bibles in the Russian Academy of Science Library. Vestnik of Saint Petersburg University. History, 2020, vol. 65, issue 2, pp. 546-565.

https://doi.org/10.21638/11701/spbu02.2020.213

The Rare Book collection of the Russian Academy of Science Library (Biblioteka Akademii Nauk, BAN) includes a number of editions in Hebrew language printed between 1500s and 1800s. The article focuses on the editions of Biblical text produced in Italy, Spain, France, Germany, Holland and England during the era of European history when religious divisions caused by Reformation encouraged Christians to seek legitimation of their confessional choice by studying and reproducing Hebrew Scripture. The Hebrew text which the Christians published became a polemical weapon employed by different groups against their opponents and against the Jews as their common Other. Nevertheless, an interest in the original Biblical text not only fostered the development of textual criticism and Biblical scholarship but also stimulated the new scholarly inter-faith and interconfessional cooperaton. BAN collection holds copies of Daniel Bomberg's Mikraot Gedolot (1547) and Biur ha-Torah (1544), Robert Estienne's Bible (1539-1542), several polyglot Biblies (Polyglotta Complutensis, Antwerp polyglot, London polyglot) and other multilingual editions with translations into Latin and other European languages. Some of these books were part of prominent private collections, such as king Sigismundus II Augustus' library of Vilno, or the home library of bishop of Tver' Theophylactus Lopatinsky. The article examines the history and influence of certain editions and studies the BAN copies with respect to their provenance, their use by the readers and their significance in the history of reading and education.

Keywords: Hebrew Bible, Russian Academy of Science Library (BAN), book history, polyglot Bible.

\section{Печатные еврейские Библии в Библиотеке Академии наук}

\section{Д. Д. Гальизин}

Для цитирования: Galtsin D.D. Printed Hebrew Bibles in the Russian Academy of Science Library // Вестник Санкт-Петербургского университета. История. 2020. Т. 65. Вып. 2. С. 546-565. https://doi.org/10.21638/11701/spbu02.2020.213

Фонд научно-исследовательского отдела редкой книги Библиотеки Российской Академии наук включает в себя печатные издания еврейских текстов, изданные между 1500 и 1800 г. В статье рассмотрены публикации библейских текстов, выходившие

Dmitrii D. Galtsin — PhD in History, Researcher, Russian Academy of Science Library, 1, Birzhevaia liniia, St. Petersburg, 199034, Russian Federation; dmitrygaltsin@gmail.com

Дмитрий Дмитриевич Гальизин - канд. ист. наук, науч. сотр., Библиотека Российской Академии наук, Российская Федерация, 199034, Санкт-Петербург, Биржевая линия, 1; dmitrygaltsin@gmail.com

(C) Санкт-Петербургский государственный университет, 2020 
в Италии, Испании, Франции, Германии, Голландии и Англии в ту эпоху европейской истории, когда в силу религиозных разногласий эпохи Реформации христиане различных конфессий обращались к изучению и публикации еврейского Священного Писания в целях легитимации собственных позиций и взглядов. В ряде случаев публикация еврейской Библии предпринималась политической элитой, которая таким образом стремилась продемонстрировать свою монополию на распространение Слова Божия и защиту веры. Печатный еврейский текст Библии мог становиться полемическим оружием, нацеленным против оппонентов-христиан и евреев как коллективного Другого. Тем не менее интерес к оригинальным библейским текстам не только способствовал развитию библеистики и научной критики текста, но также в ряде случаев приводил к межконфессиональному и даже межрелигиозному сотрудничеству. В фонде Библиотеки Российской Академии наук хранятся венецианское издание Библии Даниэля Бомберга «Микраот гдолот» (1547), библейский комментарий Бехайе бен Ашера «Биур г'аТора» (1544), Библия Робера Этьена (1539-1542), Комплютенская полиглотта (15141520), Антверпенская полиглотта Христофора Плантена (1569-1572), Нюрнбергская додекаглотта Элиаса Хюттера (1599), Лондонская полиглотта (1657-1661) и другие многоязычные издания с переводами на латынь и европейские языки. Некоторые из этих книг входили в прославленные книжные коллекции, такие как библиотека польского короля Сигизмунда II Августа в Вильно или библиотека архиепископа Тверского Феофилакта Лопатинского. В статье рассматривается история создания и влияние отдельных изданий, а также происхождение, история бытования и возможное значение экземпляров Библиотеки Российской Академии наук для истории чтения и образования.

Ключевые слова: еврейская Библия, Библиотека Российской Академии наук, история книги, Библия-полиглотта.

\section{Introduction}

The Rare Book Department of the Library of the Russian Academy of Sciences includes in its collection mostly printed books in European languages. But there are a number of early prints in Hebrew, some of which are valuable editions prominent in the Central and Eastern European history of books. I limit myself to Biblical editions printed in the period between 1500 and 1800 - the three first centuries of academic study of Hebrew in Europe, when foundations of modern Hebraistics were laid, while the "holy language" served as an important weapon in the religious confrontation between Protestants and Catholics.

Renaissance and Reformation Europe discovered the legacy of ancient cultures in their own languages, and the Hebrew language had the priviledged place among them. "Who among those who had barely heard about the Holy Writ knows not that Hebrew was the only tongue of humankind, since the world began?" wrote Jacob Koeler (1537-1612), a theologian and Hebraicist of Berlin. "It was created and founded by none other than the Son of God, the Word himself, and it is the Holy Ghost that compells us through Moses that God had employed the Hebrew tongue in creating the universe" ${ }^{1}$. Koeler's enthusiasm was shared by Elias Hütter, editor of Nuremberg polyglot (1599):

${ }^{1}$ Novum Testamentum D[omi]ni N[ost]ri Iesu Christi. Syriacè Ebraicè Graecè Latinè Germanicè Bohemicè Italicè Hispanicè Gallicè Anglicè Danicè Polonicè Studio \& Labore Eliae Hutteri Germani. Noribergae, 1599. T.2. f. [4v]. 
"In former times, since the creation [of the world] to the [building of the] Tower of Babel, and since then till Babylonian captivity, almost the same Hebrew language had been preserved intact, and this language alone was the proper [language] of the Church. In this language, as in one repertory, in one idea, all the divine revelations were contained, all human faculties, professions and arts, and they all, as if from their birth, were linked with each other. Who knew this language duly, had the easiest method to ascend to the top of every discipline. This language as proper language of God and Church, as a key to all divine and human wisdom, was retained in purity and integrity, and spread, among the idolatrous nations, by Heber, Abraham, Isaac, Jacob, Joseph, Moses, Samuel, David, Solomon, Elias and Elisha... But it was Devil's work that this holy tongue of God, together with German, is looked upon in our schools as something useless, silly and the least necessary... If Hebrew, the foundation, is laid wrongly, and the roof, that is German, altogether discarded, what can be built that wouldn't fall at the slightest strike?"2

Hebraica veritas - the "Hebrew truth" of the Holy Scripture was highly praised by the humanists who identified it with the Masora. By printing their Bibles in Hebrew, the Christians, both Protestants and Catholics, strove to go back to the sources of their religious tradition so that they could be free from error in matters of faith - but also in order to proselytise among the Jews. The intention to convert the "blinded" Jews was behind the decree of Pope Clemens V of 1311 establishing oriental language schools in the leading European universities. However, since late fifteenth century there had been a surge of interest in the Jews for their own sake: Talmudic and Kabbalistic texts became favourite subjects of study for such leading humanists as Giovanni Pico della Mirandola, Johann Reuchlin, Egidio da Viterbo and Guillaume Postel.

At the same time, the Jewish community had been using printing press since $1470 \mathrm{~s}$ as a means of preserving their own cultural and religious identity. The first printed Hebrew book in Europe (Tehilim/The Psalms) came out in 1477 in Bologna, and later the Pentateuch and other canonical scriptures printed by Gershom Soncino (Brescia, 14921494) became very influential. But it was Catholic Daniel Bomberg (d. 1553) who was considered the real leader in the Hebrew book market, having been called during his lifetime "Aldus of Hebrew book"3. His editions were most popular among the European Jewry. By the sixteenth century Hebrew had turned into a Classical language, alongside Greek and Latin, and Hebrew version was included into polyglot Bibles with parallel multilingual text.

\section{Hebrew Bibles of the sixteenth century}

Copies of Hebrew Bibles stored at the Rare Book department of Russian Academy of Science Library (RBD BAN) represent local printing traditions of Spain, France, Venice and German states. They were published between 1510s and 1790s, being all edited and published by Christians or Jewish converts to Christianity. Some of these editions, however, were crucial for the history of Jewish religion. This is especially true for the Venice editions that came from Daniel Bomberg's press. The RBD BAN holds two volumes of

\footnotetext{
${ }^{2}$ Novum Testamentum D[omi]ni N[ost]ri Iesu Christi. Syriacè Ebraicè Graecè Latinè Germanicè Bohemicè Italicè Hispanicè Gallicè Anglicè Danicè Polonicè Studio \& Labore Eliae Hutteri Germani. Noribergae, 1599. T. 1. f. [6-6v].

3 Amram D. W. The Makers of Hebrew Books in Italy: Being Chapters in the History of the Hebrew Printing Press. Philadelphia, 1909. P. 148.
} 
Bomberg's 1547 Bible (Fig. 1) - his fourth Bible edition and the last one that came out in the printer's lifetime ${ }^{4}$.

This version is usually referred to as Mikraot Gedolot or Biblia Rabbinica. It includes the Biblical Masoretic text, targums and commentaries by renowned Medieval Jewish rabbis, Rashi (r. Shlomo Yitzkhaki, 1040-1105), Radak (r. David Kimchi, 1160-1235) and Ralbag (r. Levi ben Gershom, 1288-1344). The second and third volumes contain, respectively, the "early Prophets" (Joshua, Judges, books of Samuel and Kings) and the "later Prophets" (Isaiah, Jeremiah, Ezekiel, Hosea, Joel, Amos, Obadiah, Jona, Micha, Nahum, Habbakuk, Sophonia, Hagai, Zachaiah and Malachi). The edition was completed by a Sephardic convert to Chistianity, an Augustinian monk Felice da Prato (d. 1539) and a Jewish printer and scholar Yaakov ben Hayim (d. 1538) $)^{5}$. It was the Mikraot Gedolot that became the classical version of a commented Biblical text which still retains its scholarly value today. The BAN copies originate from the library of Sigismundus II Augustus (1502-1572), Grand Duke of Lithuania, King of Poland. The super ex-libris on their case boards indicates that they were present in Sigismundus Augustus' library located in Vilnius by 1550s (perhaps, getting there together with Biur ha-Torah by $1554^{6}$ ), that is, in less that a decade since leaving the press because the cases of these copies have a "super ex libris II" (Fig. 2), according to A. Kawecka-Gryczowa's classification, impressed on them? ${ }^{7}$.

Another Venetian edition to be found in Sigismundus Augustus' library was Biur ha-Torah by $\mathrm{r}$. Behaye ben Asher (1255-1340), a commentary on the Pentateuch ${ }^{8}$. The published catalogue of Sigismundus Augustus' books stored in BAN misleadingly describes this copy as printed by Giovanni di Gara. Apparently, the name of the printer in the colophon (זואני די פארי) is considered to be a misprint. However, the famous Venetian printer Giovanni di Gara started his career later than 1544, when Behaye's book had been published. There is no misprint in the colophon, and it really speaks of Giovanni dei Farri and his brothers (ואחיו) who published the book in cooperation with Cornelio Baruch Adelkind, together with 10 other editions in the same year?.

A considerable contribution to the proliferation of Hebrew Biblical text was made by French and German printers. RBD BAN holds one volume of the first Old Testament printed by Robert Estienne (1503-1559) ${ }^{10}$. This Paris edition of 1539-1542 contained Biblical text with commentary by David Kimchi. One of the most well-known sixteenth-century translators of the Bible into Latin, Sebastian Münster (1488-1552), called his version

${ }^{4}$ Nevi'im aharonim 1547 - נביאים אחרונים עם תרגום ועם פירוש רש"י ועם פירוש רבי דוד קמחי.. ["Late" Prophets, with commentaries by Rashi, Radak (David Kimchi), Ralbag and a targum. Venice, Daniel

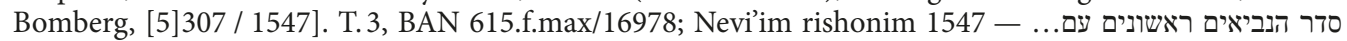
["Early” Prophets, with commentaries by Rashi, Radak and Ralbag. Venice, Daniel Bomberg, [5]307 / 1547]. T.2 (BAN, 616 f.max/16979).

${ }^{5}$ Raz-Krakotzkin A. The Censor, the Editor and the Text: The Catholic Church and the shaping of the Jewish Canon in the Sixteenth Century. Philadelphia, 2005. P.245.

${ }^{6}$ Knigi iz biblioteki pol'skogo korolia Sigizmunda II Avgusta: Katalog / ed. by E. A. Savel'eva. St. Petersburg, 1994. P.9.

7 Kawecka-Gryczowa A. Biblioteka ostatniego Jagellona: Pomnik kultury renesansowej. Wrocław, Warszawa et al., 1988. Ill. 27.

8 [Biur al ha-Torah... Venice: Giovanni dei Farri, his brothers and Cornelio Baruch Adelkind, [5]304/1544] (BAN, 1404.f/17050).

${ }^{9}$ Knigi iz biblioteki pol'skogo korolia Sigizmunda II avgusta: Katalog. P. 25; Amram D. W. The Makers of Hebrew Books in Italy. P. 199, 201; Kawecka-Gryczowa A. Biblioteka ostatniego Jagellona. S. 183 (No. 382 ).

10 [Prophetae]. Parisiis: Ex officina Roberti Stephani, typographi Regii, 1539-1541 (BAN, 211.f/4528). 


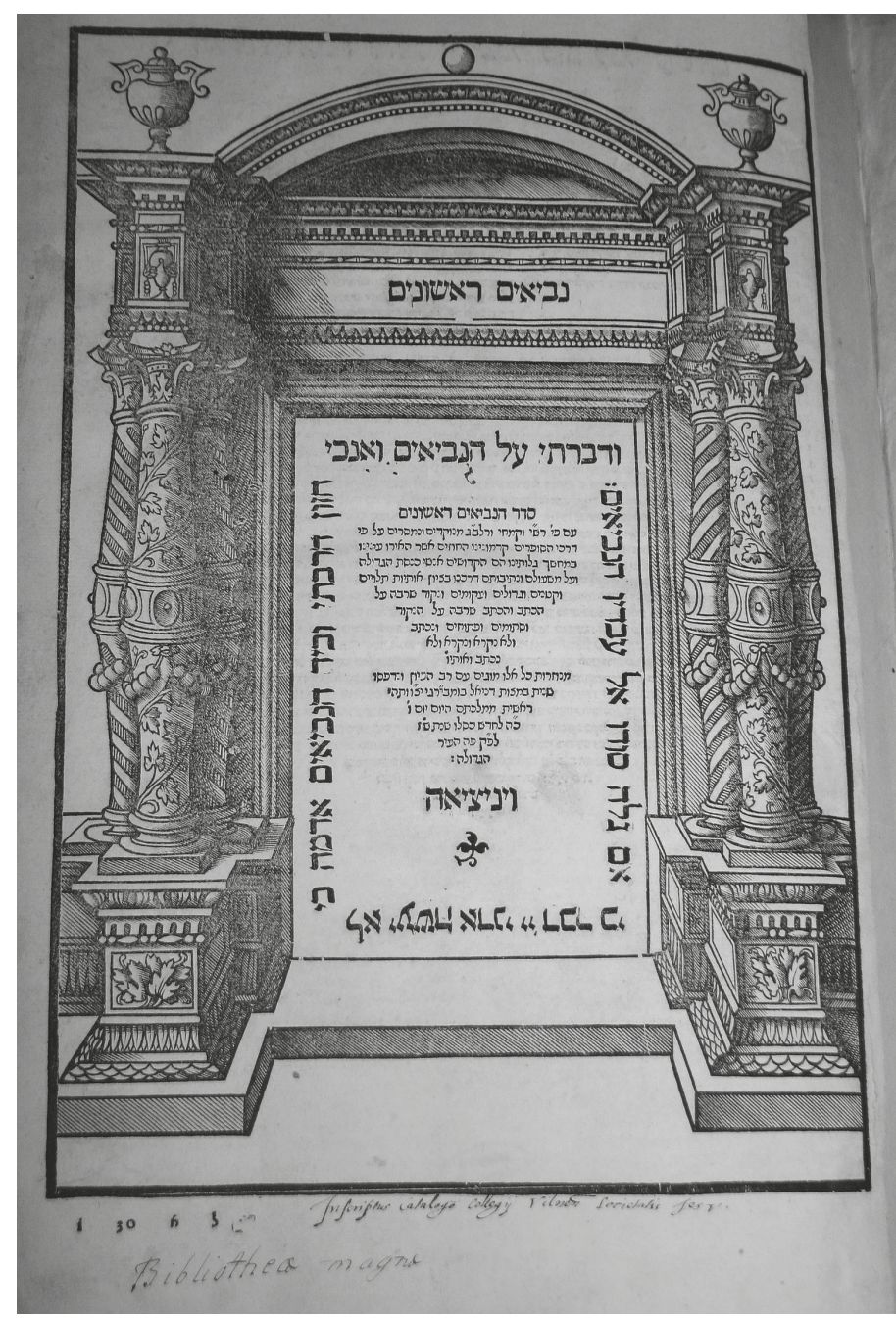

Fig. 1. Mikraot Gedolot. Venice: Daniel Bomberg, 307 / 1547. T. 2.

Title page. Photo by author

of the Hebrew Bible Mikdash Adonai, "Lord's Temple", having included in it all Hebrew biblical texts except the Prophets. In the sixteenth century this Bible came out in two editions in Basel (a different edition of Hebrew text by Münster was published without Latin translation in the printing house of Hieronymus Froben and Nicolaus Episcopius in 1536). The title page of the BAN copy (Fig. 3) has a handwritten note in Latin: "This Bible edition by Münster is the second one. The first came out of the same press in 1536 in quarto, with variants of reading. Both editions stem from the Masoretic version and for this reason alone are valuable for critical research. For their significance see Masch, p. 151. - In Rome, in 1820, it was bought by Michael Bobrowski, who was staying there, for 3 "11.

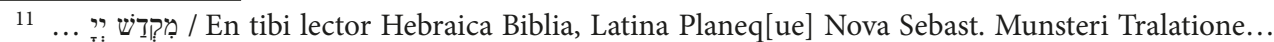
Basileae, 1546; inscript in BAN 91.f/3421: «Posterior haec est bibliorum editio facta a Munstero. Prior enim prodiit ibidem 1536. in 4to cum appendice var. lect. Utraque a masoretica est et vel sic in re critica singul. 


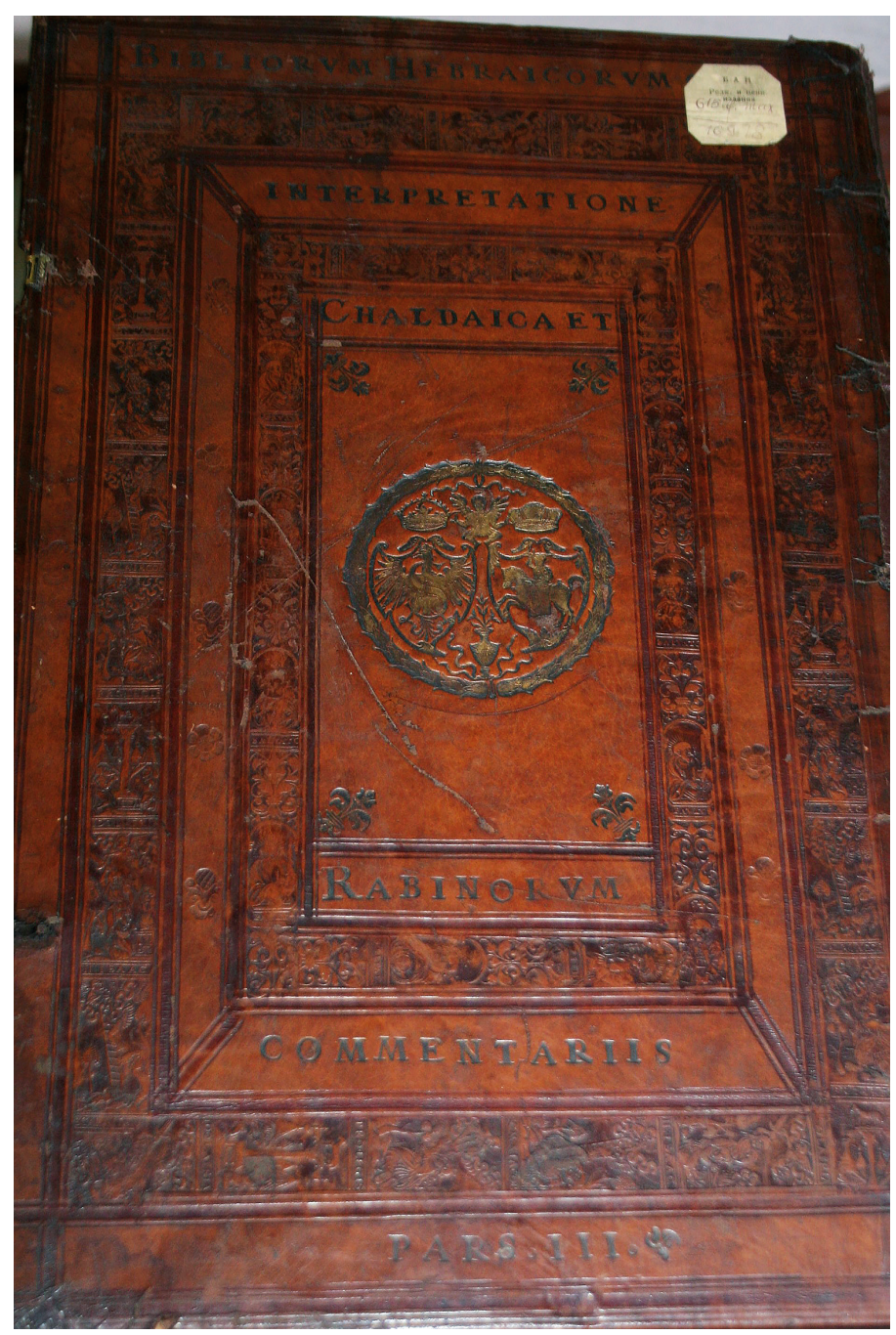

Fig. 2. Sigismundus II Augustus library cover. Photo by author

Mikhail Kirillovitch Bobrowski (1784-1848) was a well-known Slavicist and a Greek Catholic canon of the chapter of Brest. The Münster's Bible was apparently among the books which Bobrowski bought while travelling in Europe and then sold to Vilnius seminary ${ }^{12}$. The author of the note was wrong dating the first Münster's edition 1536, because it actually appeared in 1534, and not in quarto but in folio. In 1536, a different in quarto Bible, Arbaa ve-esrim, also edited by Münster, was published by Froben and Episcopius ${ }^{13}$.

emolumenti. De cuius praestantia vide Masch. P. 151. - Romae a. 1820. commoranti contigit 3. emere haec Biblia Michaeli Bobrowski».

12 Babroy̆ski Mikhail Kirylavich // Frantsysk Skaryna: Entsyklapedichny davednik. Minsk, 1988. P. 252.

13 Short-title Catalogue of Books Printed in the German-speaking Countries and German Books Printed in Other Countries from 1455 to 1600 now in the British Museum. London, 1962. P.92. For the 


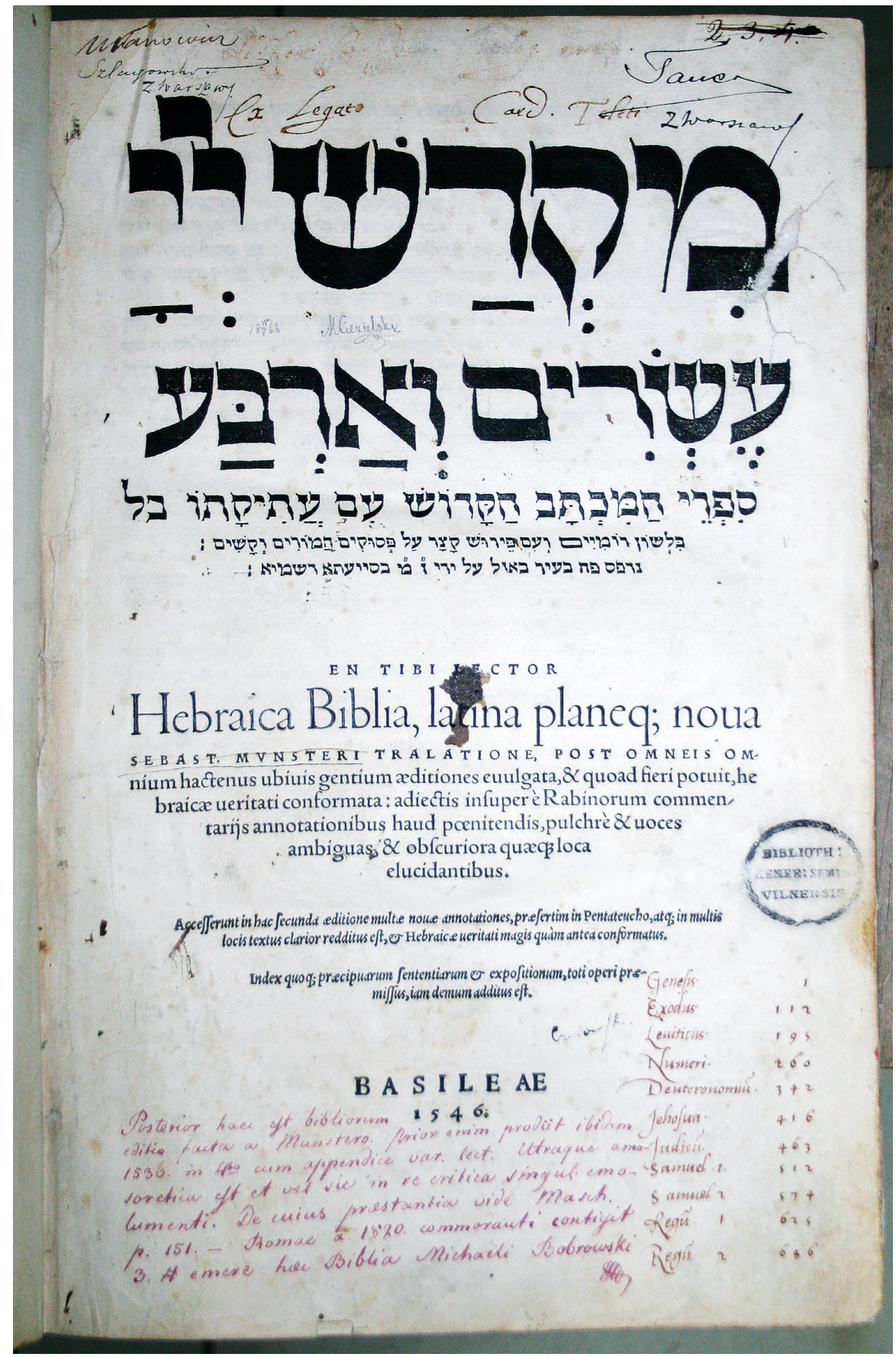

Fig. 3. Sebastian Münster's Bible, Basel, 1546. Inscription on title page [BAN, 91.f/3421]. Photo by author

history of Munster's Bibles see: Pick B. History of the Printed Editions of the Old Testament, Together with a Description of the Rabbinic and Polyglot Bibles // Hebraica. Vol. 9, 1892. P. 62-64. 
Critical study of the Biblical corpus required collation of different versions and translations of the Holy Scripture and called to life multilingual editions, the polyglot Bibles. Complutensian polyglot, or Polyglotta Complutensis, was the first among them published as a critical edition of all Old and New Testament texts in six volumes in Hebrew, Aramaic, Greek and Latin. It was sponsored by archbishop of Toledo, cardinal of Spain Francisco Ximenez de Sisneros (d. 1517). The goal of the project was to bring together the most authoritative versions of the Holy Scripture: Masoretic Hebrew text, Greek Septuagint, Latin Vulgate and Aramaic targum (Onkelos). The work on the polyglot started in 1502 being carried out by a group of scholars in the university of Alcala de Henares (the ancient Complutum). It was twelve years later that first the New Testament was published (part 6, January 10, 1514), followed by Hebrew and Aramaic ("Chaldean") lexicons of the Old Testament (part 5, March, 17 and 31, 1514). Four volumes of the Old Testament came out next bearing the date - July, 10, 1517 - in the explicit of the last volume. But the papal approval of the polyglot wasn't issued until 1520, and it was only in 1522 that the edition became available on the market. Of the 600 printed copies only 123 polyglots are known to have survived in the world by now. The BAN copy ${ }^{14}$ is a so called "Blue copy" (Fig. 4). Due to the fact that different volumes of the printed stock remained in the store for several years before they were allowed to be distributed, some copies became damaged and were in need of restoration. So fragments of the text had to be reprinted, including title-leaves for a number of copies. Unlike the original so called "Red copy", the title page of the "Blue copy" has 6 lines of the title (versus 7 lines in the "Red copy") and an ornamental engraved frame with four corners representing, in the words of J. Lyell, "a pope, a cardinal, a bishop and a mitred abbot, each bearing significant emblems of their office" 15 . It is evident, however, that we see here not simply an emblem of the four church ranks, but the four Doctors of the Church - pope Gregory I, Jerome, Ambrose and Augustine, as manifest from the lion engraved together with the cardinal, which is a standard image of Jerome, and a flaming heart in the hand of the "abbot" (Augustine).

The difference between the Red and the Blue copies was noticed by Methodist pastor Adam Clark in 1824. The polyglot variants received their names from the color of the cases the copies available to Clark were bound into. J. Lyell identified the "blue" copy as the

14 Polyglotta Complutensis - 1]....Uetus testame[n]tu[m] multiplici lingua nu[n]c primo impressum Et imprimis Pentateucu[us] Hebraico: Greco: atq[ue] Chaldaico idiomate. Adiu[n]cta vnicuiq[ue] sua latina $\mathrm{i}[\mathrm{n}]$ terpretatio[n] e. [Complutum (Alcala): in... Co[m]plutensi vniuersitate... Sumptibus... F. Francisci Ximenez de Cisneros Cardinalis Hispanie Arch[i]ep[isco]pi Toletani \& hispaniarum primatis ac Regnorum castellae Archicancellarii, Industria... Arnaldi Guilielmi de Brocario artis impressorie magistri, 1514-1520]. Pars 1; ...Secu[n]da pars Ueteris testamenti Hebraico Grecoq[ue] idiomate nunc primum impressa: adiuncta vtriq[ue] sua latina interpretatione. [Complutum: Sumptibus... F. Francisci Ximenez de Cisneros..., 1514-1520]. Pars 2 (BAN, 190 f. max/5775); [Polyglotta Complutensis - 2] ...Tertia pars Ueteris testamenti Hebraico Grecoq[ue] idiomate nunc primum impressa: adiuncta vtriq[ue] sua latina interpretatione. [Complutum: Sumptibus... F. Francisci Ximenez de Cisneros..., 1514-1520]. Pars 3; ...Quarta pars Ueteris testamenti Hebraico Grecoq[ue] idiomate nunc primum impressa: adiuncta vtriq[ue] sua latina interpretatione. [Complutum: Sumptibus... F. Francisci Ximenez de Cisneros..., 1517]. Pars 4 (BAN, 135 f. max/5701-5702); [Polyglotta Complutensis - 3] ...Uocabularium hebraicum atq[ue] chaldaicu $[\mathrm{m}]$ totius veteris testamenti $\mathrm{cu}[\mathrm{m}]$ alijs tractatibus prout infra in prefatione continetur in academia complutensi nouiter impressum. [Complutum: Sumptibus... F. Francisci Ximenez de Cisneros..., 1515]. Pars 5; Nouum testamentum grece \& latine in academia complutensi nouiter impressum... [Complutum: Sumptibus... F. Francisci Ximenez de Cisneros..., 1514]. Pars 6 (BAN, 191 f.max/5776).

${ }^{15}$ Lyell J. Cardinal Ximenez: Statesman, Ecclesiastic, Soldier and Man of Letters; with an account of the Complutensian Polyglot Bible. London, 1917. P. 36. 


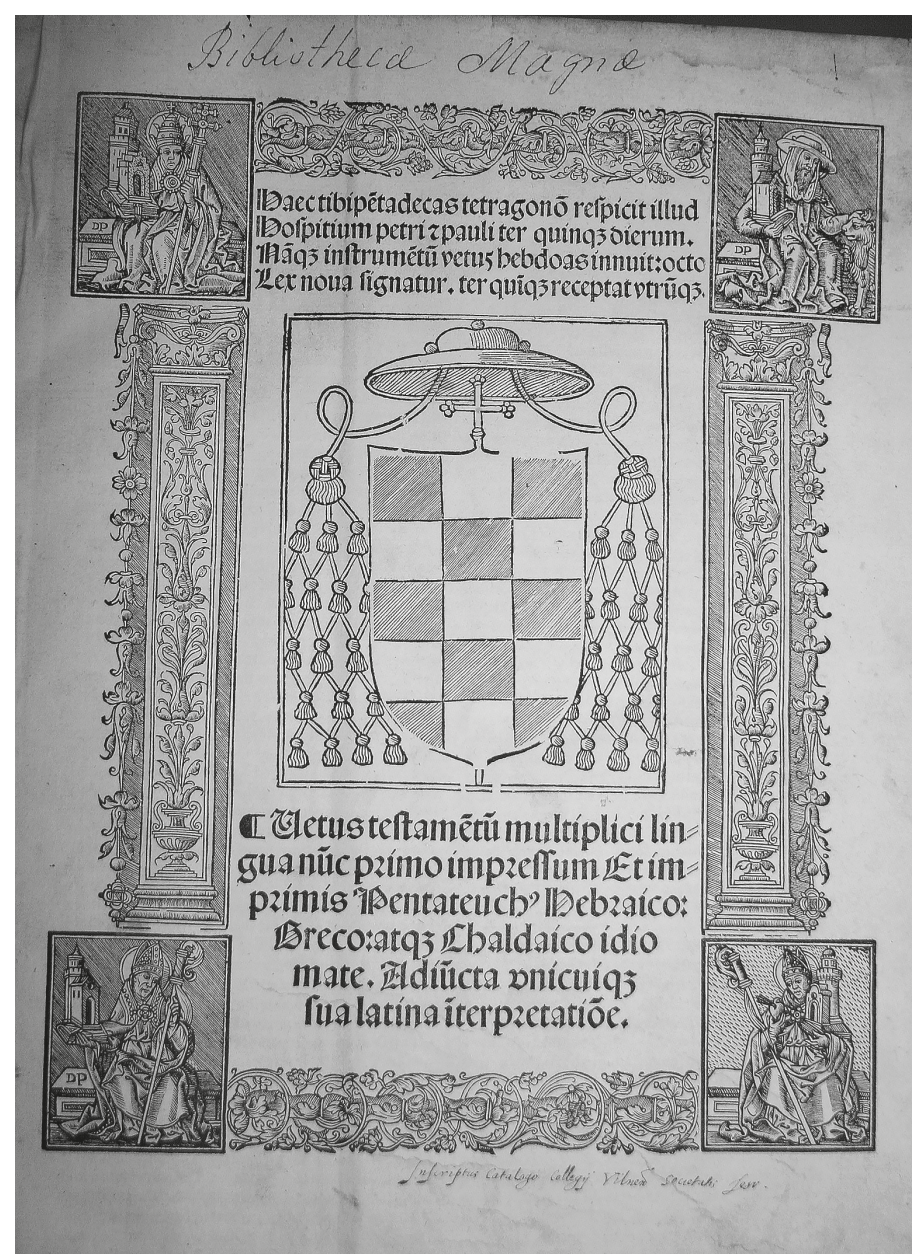

Fig. 4. Complutensian Polyglot, 1514-1520. Part 1. Title page, "Bibliotheca magna" inscription [BAN, 190 f. max/5775]. Photo by author

more rare because he could find only four "blue" copies in museums and libraries of England. He suggested that "the copies with this special title were prepared for presentation to the Pope and other high ecclesiastical and regal personages throughout Europe"16. The BAN copy of volume 3 has an inscript on its title page: "Ex Libris Serenis[simi]: Prin[cip] is", which, combined with ex libris inscriptions of "Bibliotheca magna" and the Vilnius Jesuit college, points to the initial owner of the copy in Eastern Europe - the Grand Duke of Lithuania Sigismundus II Augustus (Fig. 5). This book is not mentioned in any of the published catalogues of Sigismundus Augusus' library.

One of the most influential polyglot Bibles in the history of printing is the Antwerp polyglot, or Biblia Regia (1568-1573), sponsored by Spanish king Philipp II. The edition of this eight-volume Bible was supervised by a Spanish scholar Benito Arias Montano

${ }^{16}$ Lyell J. Cardinal Ximenez... P. 36-38. 


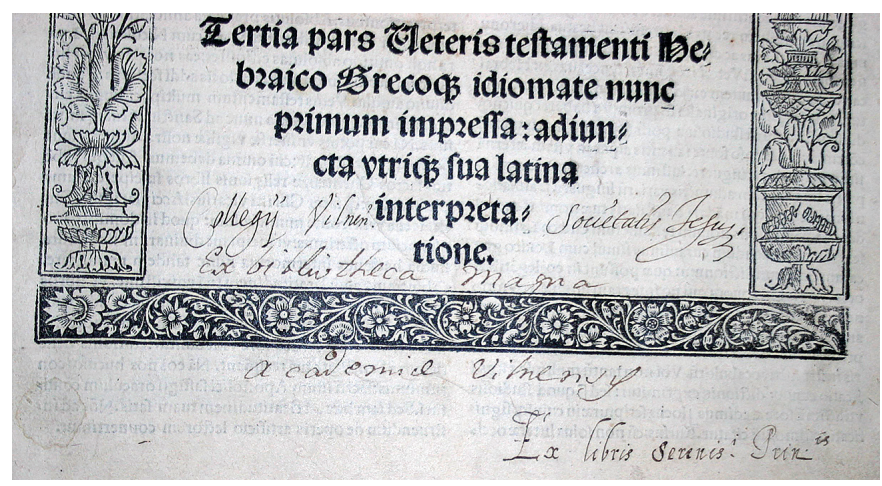

Fig. 5. Complutensian Polyglot, 1514-1520. Part 3. Owner notes on title page: Sigismundus Augustus' library, Vilnius Jesuit college, Bibliotheca magna of Vilnius Academy [BAN, 135 f. max/57015702]. Photo by author

(1527-1598) and published by a distinguished Antwerp printer Christopher Plantin $(1520-1589)^{17}$. RBD BAN holds volumes 1, 3, 4 and 7 of the Antwerp polyglot (Fig. 6), the third in two copies $^{18}$.

Textologically, this polyglot follows the Complutensian edition, but it has an interlinear Latin translation of all Hebrew text and a Syrian Peshitta (New Testament), also translated into Latin. Marginal handwritten inscriptions in the BAN copies of volumes 1 (Pentateuch) and 4 (Late prophets) mostly deal with biblical chronology and its comparison to the chronology of the classical tradition. Of a particular interest are the identical notes on the title leaves of these volumes, written by the same hand in German and Latin:

"Note. In order to understand the prophetic writings of the Jews, one shouldn't think that they speak of the events forseen in the future times; nay, these were only depictions of the time, in which a prophet wrote. We should try to find in them only the exact historical knowledge of that time, being filled with certainty that all that [according to the prophet] pertained to the future, in the enlightened eyes should be read as happening in the present. If we read, for instance, that God spoke to Moses, it should be understood thus: Moses ponders, what should be done and what should be avoided; and these thoughts and soliloquies of Moses were, according to the Jews, thoughts and words of God, who directs everything. In the same way one should understand the

${ }^{17}$ For the history of the creation of Antwerp polyglot see: Brekka P. M. The Antwerp Polyglot Bible (1572): Visual Corpus, New World "Hebrew-Indian" Map, and the Religious Crosscurrents of Imperial Spain. PhD diss. University of Florida, 2012. P. 11-22.

18 [Polyglotta Antverpiensis]. Biblia Sacra Hebraice Chaldaice Graece Latine... Antverpiae: Excudebat

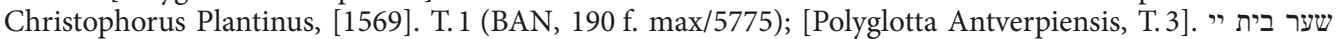
שער . של ב שרישי כתובים כתיביא

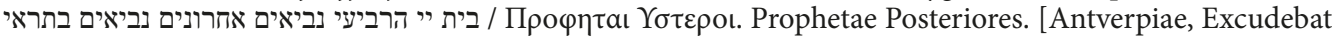
Christophorus Plantinus, 1570] (BAN, 25.f.m/3698); [Polyglotta Antverpiensis, T.7]. Novum Testamentum Graece cum vulgata interpretatione Latina Graeci contextus lineis inserta... Ben. Ariae Montani Hispalensis opera e verbo reddita... Antverpiae: Excudebat Christophorus Plantinus, 1572; Hebraicorum Bibliorum Veteris Testamenti Latina interpretatio... Antuerpiae: Christophorus Plantinus... excudebat, [1572] (BAN, 2106 f.max./1859-1860). 


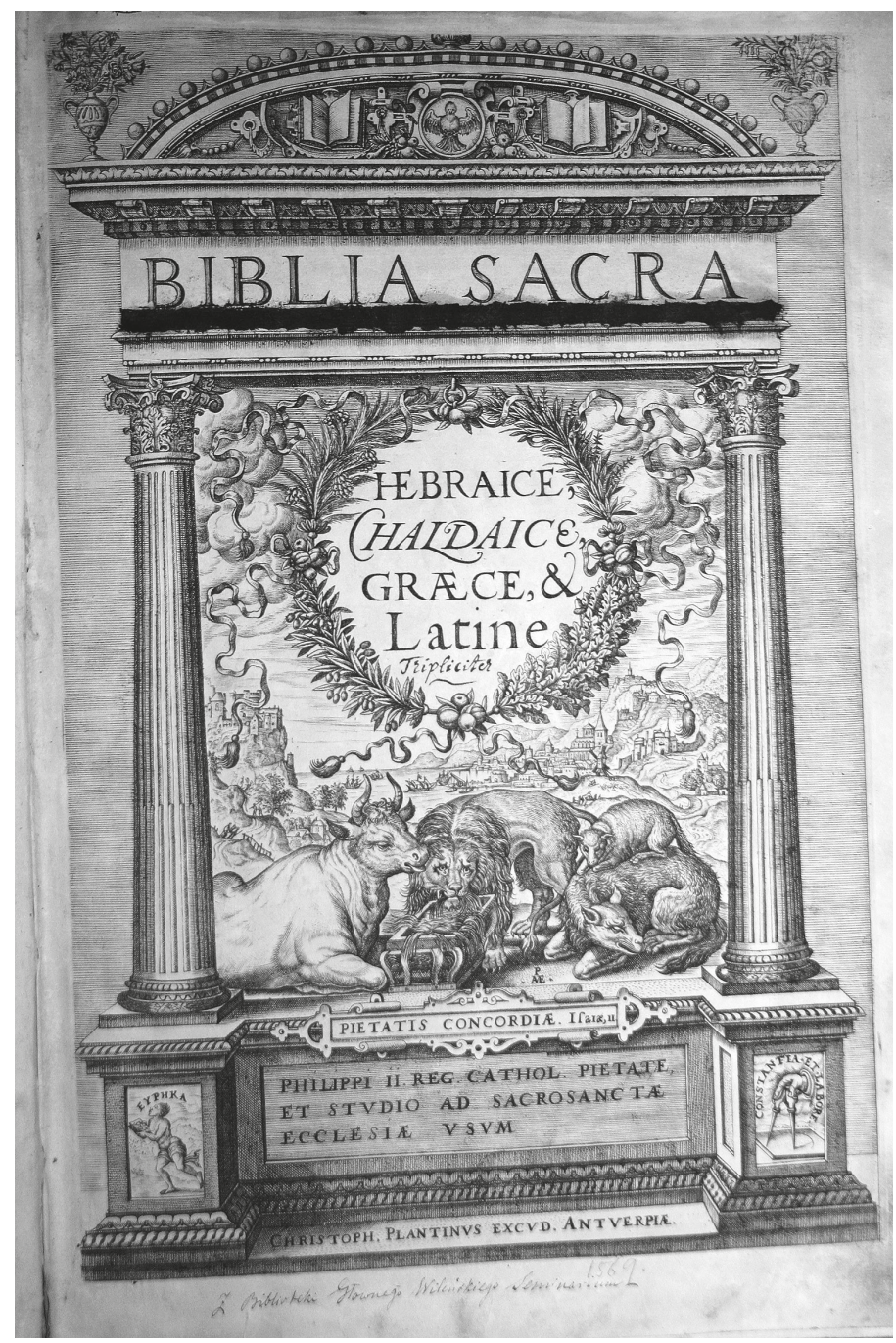

Fig. 6. Antwerp polyglot, 1569. T.1. Frontispiece. Photo by author

words "Holy Ghost", "vision", "revelation", "prophecy", when they are come across in Old and New Testament"19.

It is curious how such rationalistic hermeneutics of the Bible combined in the same author with a total trust in biblical chronology which was supported by the authority of

19 «Nota. Um die prophetischen schriften der juden zu verstehen, muß man nie glauben, als wenn darin von entfernten Begebenheiten Kunftiger Zeiten die Rede sey; Nein: Sie waren nur eine schilderung der Zeit, da der Profet schrieb. Man muß sich daher nur eine genaue historishe Kenntniß von dieser Zeit zu verschafen suchen in voller Überzeugung, daß alles, was in die Zukunft gehört, nur in die augen leuchtende unausbleiblige folgen der Begebenheiten der Zeit davon. Si legatur e:g: Deus loquitur cum Moyse, sic est intelligendum: Moyses meditatur secum ipso, quid agendum, quidve o[m]mitendum; et hae cogitationes, verbaq[ue] Moysis erant, secundum judaeos, cogitationes, et verba Dei, omnia dirigentis. Sicq[ue] verba haec: Spiritus S: — visio: — revelatio: — prophezia: — in V: et N: T: sunt intelligenda». 
classical tradition in the marginalia (the notes in volumes 1 and 4 belong to the same hand as the abovequoted "Note").

In 1587, Elias Hütter (1553-1605) published a new edition of the Bible titled Derekh ha-kodesh, or Via Sacra. Later he authored the first complete Hebrew version of the New Testament, which he published in two volumes (1599) intended as part of a prospective ten-volume Bible, called Biblia Dodecaglotta, which was suppoposed to contain a collation of Hebrew, Greek, Latin, Aramaic, Spansh, French, English, Danish, German, Polish and Czech versions of biblical texts ${ }^{20}$. The edition was funded by Nuremberg city government but failed as a commercial project because the books didn't sell, and Hütter soon died leaving large debts behind ${ }^{21}$.

Volume 1 of Derekh ha-kodesh ${ }^{22}$ is stored in Rare Book Department. Judging by the very bad condition of the tome, it was enthusiastically used by the readers, which is understandable since Hütter's Bible was printed, as stated in the title "in an elegant and majuscule characters for the easy understanding of the holy language and Scripture... [where] radical, subservient, deficient and quiescent letters can be distinguished in color and location”. It was first of all a Hebrew reader. The text is set in a very large font and certain nekudot, articles, prefixes and matres lectionis are typed in outline face. Various owners' inscriptions, all dated 1840s, testify that the copy frequently changed hands circulating among students of Catholic schools which sprouted from the Vilnius seminary disbanded in 1832. The front fly leaf also contains a blind cursive inscription in Hebrew with its considerably more readable Polish translation: “... which means: from the book collection of the Emperor's Chief Vilnius seminary bought in 1822 of Chritian era"23. With other books of the ex-seminary this Bible ended up in the library of Roman Catholic spiritual academy and was relocated to Saint Petersburg. In 1927, a part of this library confiscated by the Communist authorities was redistributed among academic institutions, including Library of the Academy of Science.

\section{Hebrew Bibles/Biblical texts of the seventeenth century}

Pierre de la Roviere, who took a Hebrew pseudonym Kepha Ilon (כאפא אילון), published Old and New Testament in the original languages in Geneva in 1617-1618. The BAN copy ${ }^{24}$ was purchased in Königsberg in 1644 by pastor Volmar Holzhausen (d. 1660) who served in Luggenhus parish in Estland. An autograph of a high ranking Estland law-

${ }^{20}$ Horne T. H. A Manual of Biblical Bibliography: Comprising a Cathalogue, methodically arranged of the Principal Editions and Versions of the Holy Scriptures... London, 1839. P. 106.

${ }^{21}$ Burnet S. G. Christian Hebraism in the Reformation Era (1500-1660): Authors, Books and the Transmission of Hebrew Learning. Leiden et al., 2012. P. 84-85; 206.

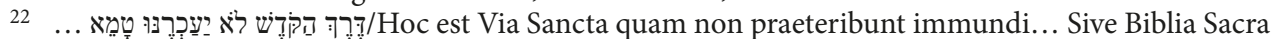
eleganti et maiuscula characterum forma, qua ad facilem sanctae linguae \& scripturae intelligentiam, nouo compendio, primo statim intuitu, literae Radicales \& Seruiles, Deficientes \& Quiescentes: situ \& colore discernuntur. Authore Elia Huttero. Hamburgi: Impressa Typis Elianis, per Ioannem Saxonem, 1587. T. 1 (BAN, 847.f.m/20643).

23 «...co znaczy: z ezbioru księg Imperatorskiey Biblioteki Głowneye Seminarium Wileńskiego ku: Roku 1822 ery Chrześciańskiey».

גנווא .חמשה חומשי תורה ... גGeneva], בבית האדון מאד אדיר כאפא אילון [Kepha Eilon, Pierre de Roviere,

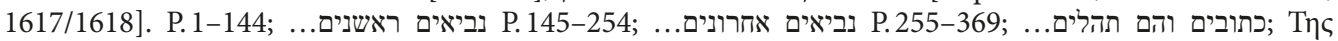

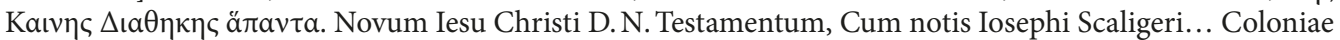
Allobrogum: Apud Petrum de la Rouiere, 1619. (BAN, 11440.q/38109-38110 R). 
yer Cornelius Murrer can also be found on the first and the last independents of this convolute volume - the title leaves of the Humash and the Greek New Testament (Fig. 7). Murrer was active in Revel (Tallinn) in the $1640 \mathrm{~s}^{25}$.

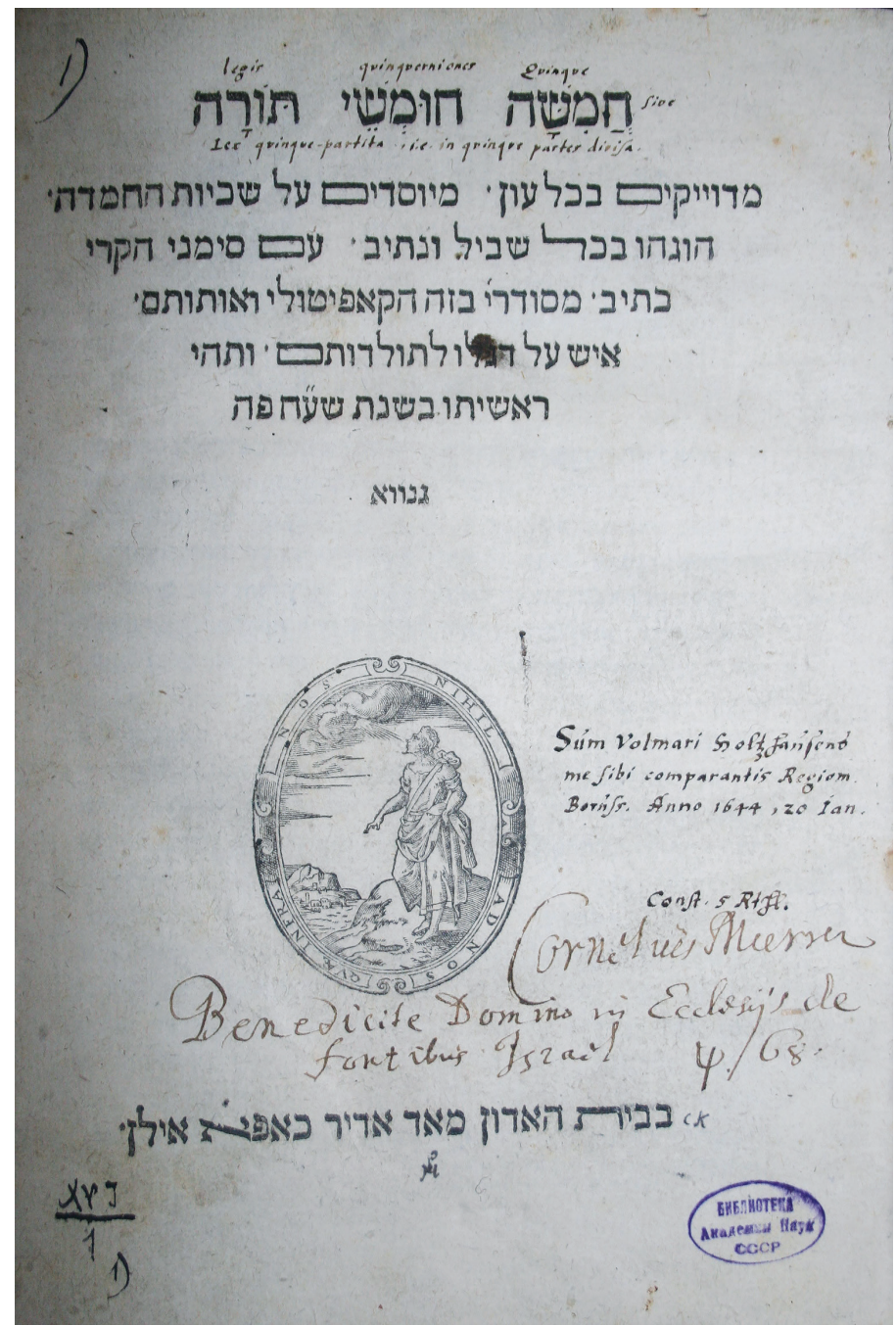

Fig. 7. Pierre de Roviere's Bible, 1617/1618. Title page with notes by Cornelius Murrer and Volmar Holzhausen [BAN, 11440.q/3810938110 R]. Photo by author

25 Autographs on title page of independednt 1: "Cornelius Murrer. Benedicite Domino in Ecclesijs de fontibus Israel $\psi . / 68$ "; "Sum Volmari Holtzhausens me sibi comparantis Regiom. Boruss. Anno 1644, 20 Ian."; and on title page of independent 5: "Cornelius Murrer emit 4 Imp[er]iali"; about Cornelius Murrer see: Klöcker M. Literarisches Leben in Reval in der ersten Hälfte des 17. Jahrhunderts (1600-1657): Institutionen der Gelehrsamtkeit und Genese städtischer Gelegenheitsdichtung. Tübingen, 2005. P.253; 312 ("Cornelius Murrerus, Palatin. per Esthon. Regii fisci advocatus, 1641"); about Volmar Holzhausen see: Recke von J.F., Napiersky K.E. Allgemeines Schriftsteller- und Gelehrten-Lexikon der Provinzen Livland, Esthland und Kurland. Mitau, 1829. Bd. II. P. 340. 
The front fly leaf is marked with a stamp of Catalogus Cameralis ${ }^{26}$ of the Academy of Science (L. TH. - from the Libri theologici section), therefore Ilon's Bible turned up in the BAN collection earlier than 1742. This copy is apparently described in the Catalogus Cameralis (Bibliothecae imperialis Petropolitanae Pars Prima, 1742) as "Nouum testamentum idiomate graeco" in the folio section: it was categorized according to its $5^{\text {th }}$ independent, the Greek New Testament, bound at the end of the convolute volume ${ }^{27}$.

Notes made by Volmar Holzhausen in the copy are numerous, and some of them are rather long. There is, for instance, a Latin mini-treatise dealing with the Hebrew text of

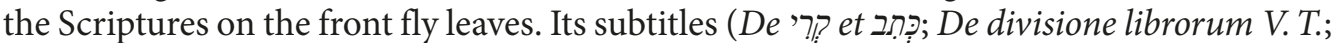

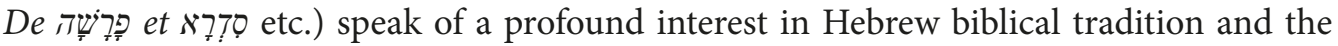
deep enthusiasm for it in the minister who lived away from the main centers of Hebrew studies in Europe. He must have acquired his mastery of Hebrew in Revel gymnasium, where he studied in the 1630s. Grammar notes on the margins of Hebrew text testify to the thoughtful reading by a learned philologist who strove to better understand the Scripture text necessary for performing his ecclesiastical duties.

Biblia Universa edited by Christian Kirchner (1657) was a reprint of Antwerp polyglot text, even including prefaces by Benito Arias Montano, but it was represented as solidly Protestant and dedicated to Johann Georg II, Elector of Saxony. Unlike the baroque symbolism of Biblia Regia front page, the engraved title of Kirchner's Bible illustrates the supremacy of Scripture text (mikre) as a triumph of Hebraica veritas and at the same time the universality of Christ's salvific sacrifice, in which all nations may participate through the Protestant principle of sola Scriptura (Fig. 8).

Judging by the presentation inscription, the BAN copy was donated in 1873 to Roman Catholic Spiritual Academy in Saint Petersburg by Konstantin Kontrym, who later (1899) became prepositor of the Ascension church in Vilnius and preceptor of two religious schools ${ }^{28}$.

A new polyglot in six volumes was edited in 1654-1657 in London by a group of scholars, including Edmund Castell, Samuel Clark, Herbert Thorndyke and others. The edition was co-ordinated by an Anglican priest (later bishop) and scholar Brian Walton (1600-1661). This polyglot was intended by Walton to be more comprehensive, correct and covering the biggest number of Scripture versions than all the former polyglots. He was apparently trying to surpass the Paris polyglot of 1695. It included, alongside the classical Hebrew, Aramaic, Greek and Latin texts also Arabic, Samaritan, Syrian, Persian and Ethi-

26 This is the standard moniker (Kamerny katalog) for the first printed catalogue of the Academy of Science Library published in 1742.

27 Bibliothecae imperialis Petropolitanae Pars Prima, quae continet libros theologicos. [Petropoli], 1742. P. 4 , no. 38 .

28 Biblia Universa et Hebraica quidem cum Latina interpretatione Xantis Pagnini Lucensis Benedicti Ariae Montani Hispal. et quorundam aliorum Collato studio ad Hebraicam dictionem diligentissime expensa. Lipsiae: Impensis Christiani Kirchneri bibliop, 1657 (BAN, 942.f.m/6555R); presentation inscrription on the front fly leaf: "Hunc Librum Constantinus Kontrym Vicarius Czesejensis offert R. C. E. Petropolitanae Academiae 1873 Februarii 2 die" (repeated on pages 54, 169, 184, 200, 283); about Konstantin Kontrym see Elenchus omnium ecclesiarum et universi cleri Dioeceseos Vilnensis pro anno Domini 1904 conscriptus // Directorium horarum canonicarum et Missarum pro Diocesi Vilnensi in Annum Domini bissextilem MCMIV, juxta Kalendarium a Sede Apostolica 1901 a. approbatum compositum. Vilnae, 1904. P. 158; 217: "Eccl. Montis Salvator, sub tit. Ascens. Dni, murata, a. 1695 a Theophilo Plater fund. Praepos. Constantinus Kontrym, S. Th. M"; "Kontrym Constantinus, S. T. M. Cur. Viln Eccl. Mont. Salvat, praeceptor. Ostrobr. et Rajsc. Scholarum”. 


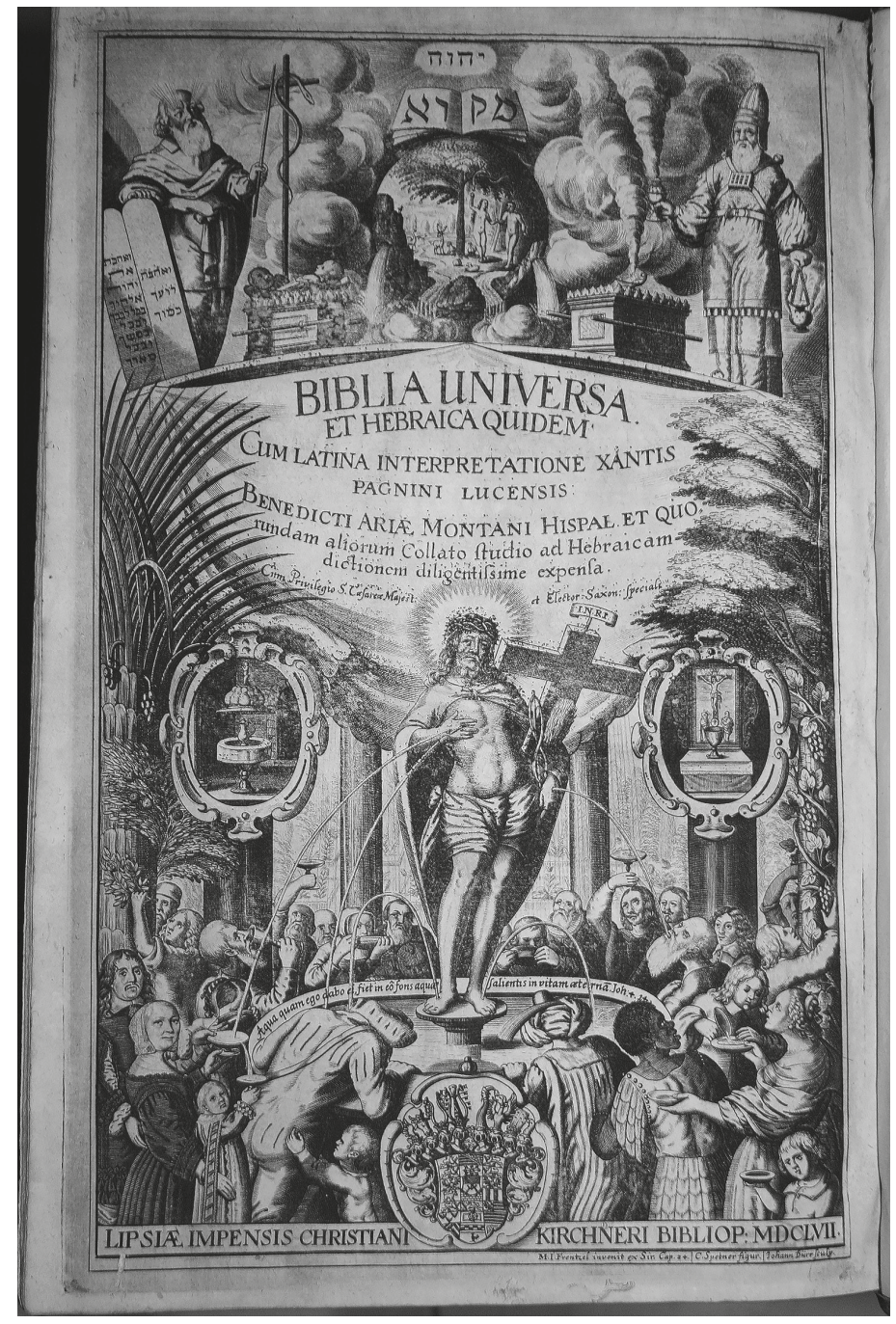

Fig. 8. Biblia Universa et Hebraica. Leipzig, 1657. Engraved title page. Photo by author

opian versions. First volumes of London polyglot left the print under the Commonwealth. The Lord Protector Oliver Cromwell was himself interested in the project and helped it administratively, though Walton was known as a staunch royalist and high-churchman. The edition was funded by subscription, the first occasion of such sponsorship in the history of English printing. The initial version of the Bible had a dedication to Cromwell; later it was replaced by a dedication to Charles II (the so called "loyal" version) ${ }^{29}$.

The unconditional trust in Masoretic tradition by Sonchino and Bomberg, characteristic of the sixteenth century editions, started to wane after Hebraicist Johann Buxtorf

${ }^{29}$ Horne T. H. A Manual of Biblical Bibliography. P. 37-38. - On the history of London polyglot see: Todd H. J. Memoirs of the Life and Writings of the Right Rev. Brian Walton... London, 1821. Vol. I. P.31-88. 


\section{B I B L I A S A C R A POLYGLO'T'TA,}

COMPLECTENTIA

Textus Originales, $\left\{\begin{array}{l}\text { HE B R A I C UM, cumPen- } \\ \text { tareucho Samaritano, }\end{array}\right\}\left\{\begin{array}{l}\text { CHA L A I C UM, } \\ \text { GR \& C UM. }\end{array}\right.$

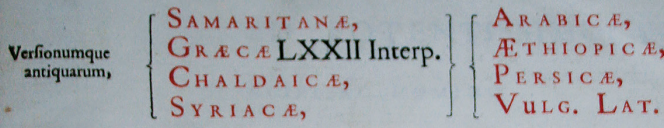

Quicquid comparari poterat.

Cum Textuum, of Verfonum Orientalium Tranflationibus Latinis. E X

VETUSTISSIMIS MSS. UNDIQUE CONQUISITIS, optimífque Exemplaribus imprefsis, fummâ fide collatis.

Qux in prioribus Editionibus deerant fuppleta. Multa antehac inedita, de novo adjecta. Omnia co ordine difpofita, ut Textus cum Verfionibus uno intuitu conferri poffint.

Cum Apparatu, Appendicibus, Tabulis, Varits Lectionibus, Anotationibus, Indibus, \&ci

Opus totum in fex Tomos tributum.

\section{Edidit BRIANUS VVALTONUS, S. T. D.}

Rationes quibus Opus boc Jufceptum,

Quorum Auf piciis \& munificentia promotum,

Quorum collatis fudiis of laboribus perfectum,

Quidque in bac Editione pre reliquis preftitum, Sequens Prafatio indicabit.

\section{LONDINI,}

Imprimebar THOMAS ROYCROFT,

M DC LVII.

Fig. 9. London polyglot. 1657. T.1. Title page with owner notes [BAN, 338 f.m./13124]. Photo by author

(1564-1629) ${ }^{30}$ had begun critical studies of the Masora itself. According to Walton, the oriental versions of Scripture could help to restore the "original" Hebraica veritas as revealed by God himself. Perceived as being closer to the "original", they were considered to be less subject to the deliberate or indeliberate scribal errors. The publishers looked upon historical commentary on the text as no less important than the text itself. Thus, London polyglot became a complete encyclopedia of Oriental and Biblical studies, its marvellous engraved illustrations making it an exemplar biblical edition for at least two centuries.

${ }^{30}$ For the role J. Buxtorf played in Biblical citicism see: Burnet S. G. From Christian Hebraism to Jewish Studies: Johannes Buxtorf (1564-1629) and Hebrew Learning in the Seventeenth Century. Leiden et al., 1996. 
The BAN copy (volume 1 with Pentateuch and prefaces, amounting up to a half of the whole tome) originates from the library of Roman Catholic Spiritual Academy, and had been part of Vilnius seminary library in early nineteenth century. The owner's inscriptions on the title (Fig. 9) show that some "Felicianus Estignard" was probably its first owner, and that it was bought in 1695 in London by theologian and Classicist Gottfried Olearius (1672-1715), who would later become professor and rector of Leipzig university ${ }^{31}$.

Not only large and erudite editions of the biblical corpus in Hebrew, but also small and popular books intended for study or reference appeared on the market in the seventeenth century. One of such popular editions was Psalterii Davidis editio nova (1650) by Anton Hüls (1615-1685) in duodecimo ${ }^{32}$. Though the text was the product of a rather serious study, as Hüls also published several Hebrew Bible editions and a Hebrew-Latin dictionary, the Psalter is first and foremost a book for pious reading. A note in the BAN copy, mirroring the fragment in the preface, testifies to such use: "Who will deny that Psalter, this most miraculous compendium, may be called a small Bible?... [I]t embraces the whole celestial doctrine, the word of the Law and the Gospel, which it doesn't only expound but illustrates with the examples most noble"33.

The Orientalist Henrich Opitz (Opitius, 1642-1712), professor from Kiel, published a shortened version of the Bible (Biblia parva, 1673) as a Hebrew manual. The BAN copy ${ }^{34}$ was purchased in 1679 by one Christian Clemens Kessler (apparently, in Hamburg), who wrote his name in Hebrew, Greek and Latin on the title page ("Kтr $\mu \alpha$ Christ. Clem.

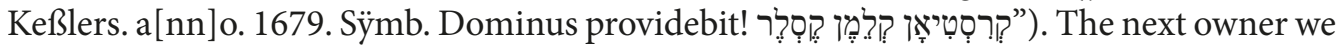
can trace was archbishop of Tver' Theophylactus (Feofilakt) Lopatinsky (c. 1680-1741). Lopatinsky, being made archbishop in 1725, collected a library which formed the core of Tver' seminary library since 1743. In the 1920s the rare books of the seminary, which by then had been abolished, were given to Kalinin pedagogical institute, and from that institute they were removed to BAN in 1959, where they are now stored as a memorial “Theophilcatus Lopatinsky's Library"35.

${ }^{31}$ Biblia Sacra polyglotta, comlectentia Textus Originales, Hebraicum, cum Pentateucho Samaritano, Chaldaicum, Graecum. Versionumque antiquarum, Samaritanae, Graecae LXXII Interp. Chaldaicae, Syriacae, Arabicae, Aethiopicae, Persicae, Vulg. Lat. Quicquid comparari poterat. Cum Textuum, \& Versionum Orientalium Translationibus Latinis... Cum Apparatu, Appendicibus, Tabulis, Variis Lectionibus, Annotationibus, Indicibus, \& Opus totum in sex Tomos tributum. Edidit Brianus Waltonus... Bibliorum Sacrorum Tomus Primus: Sive Pentateuchus Moysis. Londini, Imprimebat Thomas Roycroft, 1657. T. 1 (BAN, 338 f.m./13124); inscription of the engraved title page: "z Biblioteki Glownego Wilen: Seminarium"; owner inscriptions on title page: "Felicianus Estignard"; "Gottfridus Olearius Lupsiensis Londini 1695".

32 תהלים Psalterii Davidis Editio Nova, Priore emendatior... Ex variis cum Christianorum tum Ebraeorum interpretum monumentis erutae, \& in Hebraizantium gratiam concinnatae per Antonius Hulsium. Lugduni Batavorum: Ex Officina Ioannis Maire, 1650 (BAN, 1323.o/6940).

${ }^{33}$ Note on the back of the front fly leaf: «Psalterium, $\pi \dot{\alpha} \gamma \chi \rho\llcorner\sigma \tau o v$ illum $\sigma \dot{\lambda} \lambda \lambda \alpha \beta o v$, parva vocari posse Biblia, q[ui]s e[ni]m neget? Inprimis quando $\mathrm{p}$ [er]pendit, totam $\mathrm{d}[\mathrm{oct}] \mathrm{r}[\mathrm{in}]$ am caelestem, verbu[m] Legis et Evangelij comprehensam, non min[us] copiosissimè inibi comprehendi, quam exemplis illustrari, nec non confirmari nobilissimis».

34 Biblia parva hebraeo-latina, In quibus dicta insigniora omnia ex universô Codice Hebraeô sec. ordinem Libb. Biblicorum, \& in his Maxima pars Vocum Hebraicarum \& Chaldaicarum Codicis S.cum curâ exhibentur In Usum SS. Theol. et Sacratioris Philologiae Cultorum adornata à M. Henrico Opitio... Hamburgi: Sumptibus Autoris, 1673 (BAN, 42-L); description in: Biblioteka Feofilakta Lopatinskogo (ok. 1680-1741): Katalog / eds by D. D. Gal'tsin, G. N. Pitul'ko. St. Petersburg, 2016. P. 20-21, no. 8.

${ }^{35}$ For the history of Lopatinsky's collection see: Pitul'ko G. N. K voprosu ob izuchenii i nauchnom opisanii knig iz sobraniia Feofilakta Lopatinskogo // Kniga v Rossii. Moscow, 2006. Sb. 1. P. 234-240. 


\section{Hebrew Bibles of the eighteenth century}

There are also four copies of eighteenth-century Hebrew Bible editions that should be mentioned in this overview. First, it is the Bible published in 1720 by Johann Georg Michaelis (1668-1738), professor at Halle ${ }^{36}$.

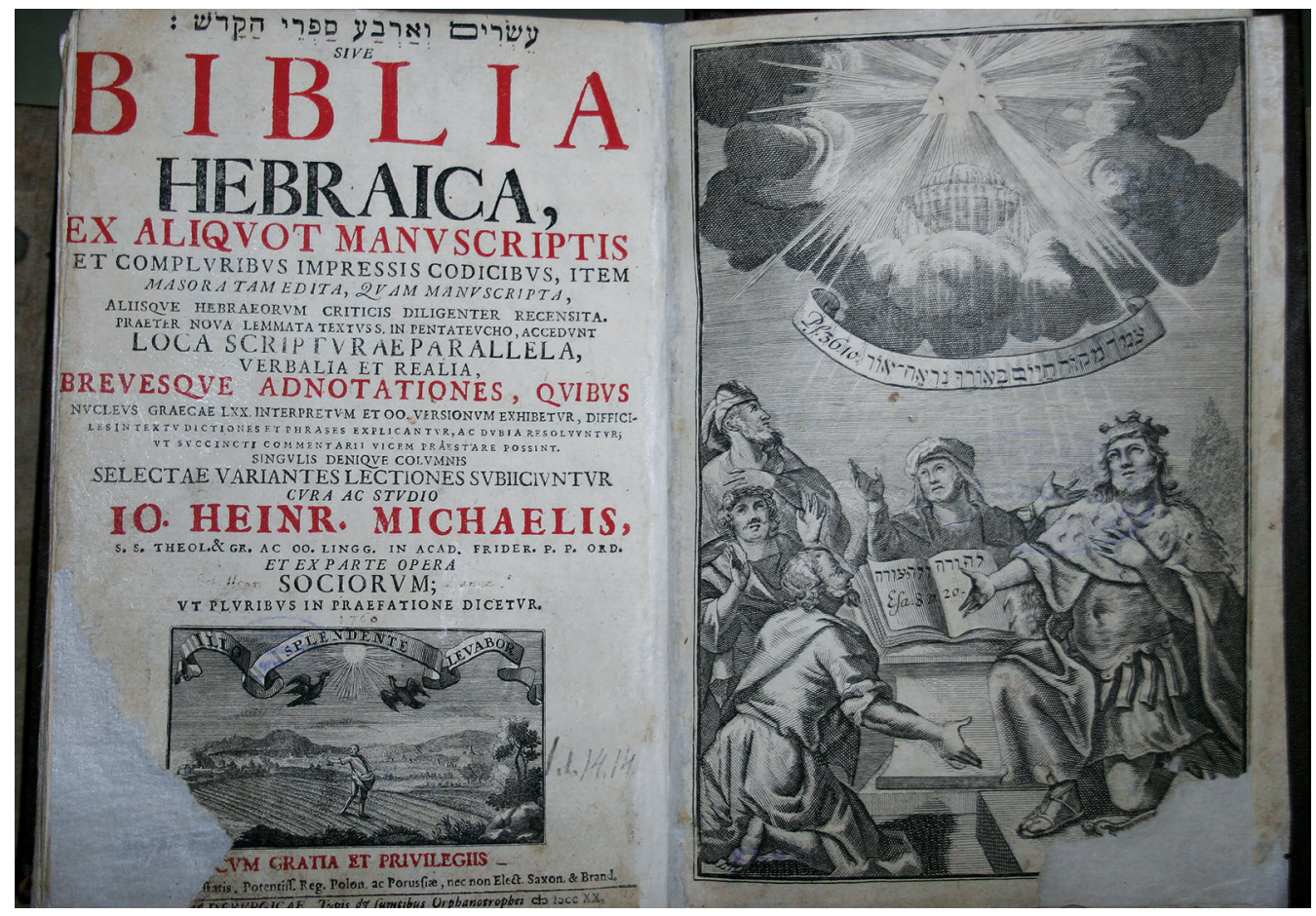

Fig. 10. Michaelis Bible, Halle, 1720. Photo by author

This Bible is important in the history of biblical print because it makes a step further in critical work on the text. Taking into consideration Buxtorf's version of Biblical text, Michaelis was the first to employ the Erfurt codices placing their lecture variants in the margins. One Michaelis Bible is in "Theophilcatus Lopatinsky's Library" (Fig. 10; BAN, $1860-\pi)$. It was purchased in Europe by a wandering Russian cleric Palladius Rogovsky (or Rogov, died 1703), who later, on his return to Russia, became an archimandrite and rector of Moscow Academy (later - Slavonic-Greek-Latin academy). The reverse of the frontispiece has an inscription: "Archimandritae Palladii". The book was inherited by Theophylactus Lopatinsky, who was also a rector of Moscow Academy and took the Bible with him when he was made archbishop of Tver' and moved to his see. Anoher BAN copy of the same edition (BAN, 10142.q/29619R) contains a curious Latin note with textual statistics of the Bible as to the number of its chapters (929), verses (23202), books (22 or 39), and the volume of Hebrew and Aramaic thesaurus (5642), including unica (1500). The back

36 Sive Biblia hebraica, ex aliquot manuscriptis et compluribus impressis codicibus, item Masora tam edita, quam manuscripta, aliisque Hebraeorum criticis diligenter recensita... Cura ac studio Io. Henr. Michaelis... Halae Magdeburgicae: Typis \& sumtibus Orphanotrophei, 1720. 
fly leaf also contains a note dealing with the question whether the Proverbs and the Canticles are texts inspired by God.

A four-language edition of 1750 in Hebrew, Greek, Latin and German by Christian Reineck (Reineccius, 1668-1752) ${ }^{37}$ is also noteworthy. The German Luther's version being included into the text shows that this book was intended not only as a critical edition, but also as a preacher's Bible, which could be used for expounding the holy writ in the sermons. The BAN copy belonged to the Academy member Izmail Ivanovich Sreznevsky (1812-1880), one of the most prominent Slavicists of the ninetenenth century. It has a stamp "I. I. Sreznevsky's library" (Biblioteka I. I. Sreznevskogo) on the fly title. A reprint of Reineck's Bible, stored at BAN ${ }^{38}$ comes from the rich book collection of a renowned church historian, member of the Academy Nikolai Konatsntinovich Nikol'sky (1863-1936), who was the first director of BAN in 1920-1925. Its back fly leaf bears a stamp "From N. K. Nikol'sky's library" (Iz biblioteki N. K. Nikol'skogo).

\section{Conclusion}

The Hebraica Veritas of the Bible could be defended from different points of view in the period. Sebastian Münster wanted to rid the Christian world of the Vulgate by publishing his Latin version of the Old Testament. Philipp II who ordered the edition of Biblia Regia was interested in representing himself as a new Solomon or Josiah and his empire as the New Israel. The Hebrew text which the Christians had been publishing became during the Reformation a polemical weapon each religious and political group employed against its opponents and against the Jews as the common Other, who had inhabited the baptized world for centuries. Nevertheless, an interest in the Hebrew Bible text not only fostered the development of textual criticism and Biblical scholarship, but also stimulated the new scholarly inter-faith and interconfessional cooperaton. Bomberg's Bible and Antwerp polyglot were both products of work by international and even interdenominational teams, which contributed in the long run to the overcoming of religious and ethnic bias.

\section{References}

Amram D. W. The Makers of Hebrew Books in Italy: Being Chapters in the History of the Hebrew Printing Press. Philadelphia, Julius H. Greenstone, 1909, 417 p.

Burnet S. G. Christian Hebraism in the Reformation Era (1500-1660): Authors, Books and the Transmission of Hebrew Learning. Leiden et al., Brill, 2012, 343 p.

Horne T.H. A Manual of Biblical Bibliography: Comprising a Cathalogue, methodically arranged of the Principal Editions and Versions of the Holy Scriptures... London, T. Cadell et al., 1839, 432 p.

Kawecka-Gryczowa A. Biblioteka ostatniego Jagellona: Pomnik kultury renesansowej. Wrocław, Warszawa et al., Zakład Narodowy im. Ossolińskich, 1988, $341 \mathrm{s.}$

Klöcker M. Literarisches Leben in Reval in der ersten Hälfte des 17. Jahrhunderts (1600-1657): Institutionen der Gelehrsamtkeit und Genese städtischer Gelegenheitsdichtung. Tübingen, Max Niemeyer Verlag, 2005,652 S.

${ }^{37}$ Biblia sacra quadrilinguia Veteris Testamenti hebraici cum versionibus e regione positis, utpote versione Graeca LXX interpretum..., item versione Latina..., et Germanica... accurante M. Christiano Reineccio. Lipsiae: Sumptibus haeredum Lanckisianorum, 1750 (BAN, 2587.f/27590.R).

38 Biblia hebraica olim a B. Christiano Reineccio edita... nunc denuo... ediderunt D. Io. Christoph. Doederlein... et Ioannes Henricus Meisner... Lipsiae: [Imp]ensis I. G. I. Breitkopfii et Soc., 1793 (BAN, 15245.o/29906.R). 
Lyell J. Cardinal Ximenez: Statesman, Ecclesiastic, Soldier and Man of Letters; with an account of the Complutensian Polyglot Bible. London, Grafton and Co., 1917, 119 p.

Raz-Krakotzkin A. The Censor, the Editor and the Text: The Catholic Church and the shaping of the Jewish Canon in the Sixteenth Century. Philadelphia, Pennsylvania State Press, 2005, 328 p.

Recke von J.F., Napiersky, K.E. Allgemeines Schriftsteller- und Gelehrten-Lexikon der Provinzen Livland, Esthland und Kurland. Mitau, Bey Johann Friedrich Steffenhagen und Sohn, 1829. Bd. II, 620 S.

Brekka P. M. The Antwerp Polyglot Bible (1572): Visual Corpus, New World "Hebrew-Indian" Map, and the Religious Crosscurrents of Imperial Spain. PhD diss. University of Florida, 2012, $264 \mathrm{p}$.

Pick B. History of the Printed Editions of the Old Testament, Together with a Description of the Rabbinic and Polyglot Bibles. Hebraica. 1892, vol.9, pp.47-116.

Burnet S. G. From Christian Hebraism to Jewish Studies: Johannes Buxtorf (1564-1629) and Hebrew learning in the Seventeenth Century. Leiden et al., Brill, 1996, 329 p.

Todd H. J. Memoirs of the Life and Writings of the Right Rev. Brian Walton... London, C. \& J. Rivington et al., 1821. Vol. I, $391 \mathrm{p}$.

Pitulko G. N. Concerning the Study and Description of Books from the Library of Feofilakt Lopatinsky. Kniga $v$ Rossii, 2006, Sb. 11, pp. 234-240. (In Russian)

Статья поступила в редакцию 3 октября 2019 г. Рекомендована в печать 12 марта 2020 г. Received: October 3, 2019 Accepted: March 12, 2020 